\title{
Tax Footnotes Readability and CEO Narcissism: Evidence from Indonesia
}

\author{
Arfian Erma Zudana ${ }^{*}$, Kiddy Novian², Rakha Pangestu Setiawan ${ }^{3}$, Sherlin $^{4}$ \\ 1,2,3,4 Accounting Department, Faculty of Economics and Communication \\ Bina Nusantara University \\ Jakarta 11480, Indonesia \\ arfian.zudana@binus.edu; kiddy.novian@binus.ac.id; rakha.setiawan@binus.ac.id; \\ sherlin@binus.ac.id
}

*Correspondence: arfian.zudana@binus.edu

\begin{abstract}
CEO Narcissism has the potency to influence individual characteristics positively or negatively. We aim to examine the relationship between narcissism as CEO-level characteristics and tax footnotes readability. We measure narcissism using the CEOs' photos on the firms' annual reports. Using 799 firm-year Indonesia listed firms from 2015 through 2019, we find that higher CEO narcissism is related to a higher tax footnote readability. This result is robust for alternative measures of readability. By examining the relationship between CEO narcissism and tax footnotes readability, we provide an additional important factor to boards for consideration during the CEO selection. We also offer insight for shareholders or investors to consider CEO traits, namely narcissism, in assessing and interpreting tax footnotes readability.
\end{abstract}

Keywords: CEO characteristics; CEO narcissism; Tax Footnotes; Readability.

\section{INTRODUCTION}

Since Li (2008) 's seminal work, annual report readability has been extensively studied (see for example, Lehavy et al. (2011); Ajina et al. (2016); Ertugrul et al. (2017); Lo et al. (2017); Lim et al. (2018) find that 80 per cent of the report consists of narrative disclosures, and importantly, it helps the users of the report to understand the numbers disclosed. In this study, we try to shed light on the relationship between CEO-level characteristics, namely narcissism, and tax footnotes readability which is specific information regarding the tax position of a firm (Inger et al., 2018).

The upper echelon theory suggests that firm-level decisions and behaviour are affected by managers' experiences, values, and personalities (Hambrick and Mason, 1984). Several previous studies already examine the influence of CEO-level characteristics (see, for example, Malmendier and Tate (2005); Huang et al. (2012); Ali and Zhang (2015); Kim et al. (2016); Kubick and Lockhart (2017)). For example, Hirshleifer et al. (2012) find a positive relationship between CEO overconfidence and innovation as measured by patents and patent citations. Exploiting the CEO's hobby, Sunder et al. (2017) find that the hobby of flying an airplane is positively related to innovation outcomes, innovation effectiveness, and diversity and originality of patents. Using different characteristics, Olsen et al. (2014) find that a higher CEO narcissism induces higher earnings per share and share price. We extend this line of research by examining the influence of CEO narcissism on tax footnotes readability.

Narcissism has the potency to affect individual characteristics positively or negatively. On the one hand, narcissism may be related to the required personal trait of a leader, such as confidence, charisma, authority, and superiority (Hogan and Kaiser (2005) and Olsen et al. (2014)). On the other hand, it is also related to several negativities such as arrogance, self-importance, exhibitionism, entitlement, inability to learn from mistakes, and self-admiration (Emmons (1987); Hogan and Kaiser (2005); and Olsen et al. (2014)). Despite those two faces 
of narcissism, some believe that it is correlated with the need for recognition and praise (Resick et al., 2009). Consequently, a narcissistic individual may engage in reckless actions, especially if that actions are an attempt to pursue opportunities (Campbell et al. (2000) and Wallace and Baumeister (2002)).

We examine the issue of CEO narcissism on tax footnotes readability for several reasons. First, tax footnotes are among the most important publicly available information regarding a firm tax behaviour (Inger et al., 2018). In that case, investors may rely heavily on the disclosure of that footnotes on their decision-making process. Second, it is the most expensive and detailed footnotes produced by firms (Raedy et al., 2011). Third, taxation is essential because it is related to both firm financial capability (in terms of cash flow)and law compliance. Therefore, a firm should take very careful action to balance the two. For example, higher tax avoidance will lead to higher cash flow. However, it may also lead to more heightened government scrutiny.

Fourth, firm tax decisions may influence the bottom line of accounting numbers. The higher the avoidance behaviour, the lower the expense, thereby increasing net income. Fifth, Inger et al. (2018) argue that tax footnotes can be used by the tax authority to limit tax avoidance. Hence, there is a trade-off between the usefulness of disclosing information to shareholders using tax footnotes and the probability that the information will be used by the government to conduct a tax audit.

Tax footnotes, therefore, can be a venue for narcist CEOs. A narcist CEO may engage in actions irrespective of the ethical perspective in their attempt to get a higher or better self-image. This may lead CEOs to manipulate the tax footnotes, thereby lowering the readability of the footnotes. However, there is also a possibility that narcissist CEOs may write a smooth footnote to protect them from government scrutiny and bad market assessments. In this case, CEO narcissism will lead to higher tax footnotes readability (more readable).

We examine the issue using the Indonesia setting because Indonesia has a small yet growing capital market. In that case, there is a higher possibility that tax footnotes are the only source of information regarding firm tax behaviour for both shareholders and the government. Consequently, there is a greater trade-off for disclosing information on the footnotes between providing a complete picture to shareholders and providing a better tool for the government to check firm tax behaviour. Several studies examine CEO narcissism using the setting in Indonesia. For example, Razak et al. (2020) find that firm value increase with the higher CEO narcissism. Using manufacturing companies as the research sample, Rispantyo (2019) finds a negative relationship between narcissism and the quality of accrual earnings.

Using 799 firm-year observations of 307 Indonesian firms listed in the Indonesian Stock Exchange in the 2015 - 2019 period. We find that CEO narcissism is negatively associated with tax footnotes readability measure. Our result is robust for the alternative use of tax footnotes readability measures. It indicates that the characteristics of narcist CEO lead to more readable tax footnotes. This may present evidence that narcist CEOs may write a smooth footnote to protect them from government scrutiny and bad market assessments, thereby protecting their self-image and reputation.

We provide several contributions by examining the relationship between CEO narcissism and tax footnote readability. First, connect the specific issue of CEO characteristics, namely narcissism and tax footnotes readability. Second, we extend prior literature on the effect of CEO characteristics on firms' behaviour (see, for example, Wallace and Baumeister (2002); Maccoby (2007); Padilla et al. (2007); Chatterjee and Hambrick (2007); Olsen et al. (2014); and Sunder et al. (2017)), especially previous literature in Indonesia that examine CEO narcissism (see, for example, Rispantyo (2019) and Razak et al. (2020)). Third, we provide additional evidence on the issue of annual report readability (see, for example, Adelberg (1979); Botosan (1997); Rutherford (2003); Courtis (2004); Bloomfield (2008); Li (2008); Miller (2010); Lehavy et al. (2012); Lawrence (2013); Lo et al. (2017); Ajina et al. (2016)), especially related to the tax footnote readability (see, for example, Inger et al. (2018)). Fourth, we provide an additional important factor to boards for consideration during the CEO selection. Fifth, our study provides insight for shareholders or investors to consider CEO traits, namely narcissism, in assessing the credibility of a firm's tax footnotes.

We structure our paper as follows: Section 2 shows the hypothesis development on the relationship between CEO narcissism and tax footnotes readability. In Section 3, we present our sample and research design. The descriptive statistics of our sample and the results of the baseline regression are presented in Section 4. Finally, we conclude the paper in Section 5. 


\section{Hypothesis Development}

The social-personality literature conceptualizes narcissism as a normally distributed trait in the population and for which there is no qualitative cut-off (taxon) for elevated narcissism (Foster and Campbell, 2007). Ham et al. (2018) identify narcissism as a stable personality trait that can be measured with personality assessment tools.

There has been long-standing research to examine the effect of narcissism as one of the executive traits (see, for example, Emmons (1987); Wallace and Baumeister (2002); Hogan and Kaiser (2005); Maccoby (2007); Padilla et al. (2007); Chatterjee and Hambrick (2007); and Olsen et al. (2014)). In an experimental setting, Wallace and Baumeister (2002) find a positive relationship between narcissism and performance when the tasks are more complex. They argue that it is evidence that narcist individuals prefer high pressure in which there will be a higher reward for success and costs of failure. Regarding the decision process, Aktas et al. (2012) find that the narcissism of the acquirer CEO is related to a higher takeover initiation and faster negotiation. On the contrary, CEOs' narcissism of both acquiring and target is connected to a lower probability of takeover deals. O'reilly et al. (2013) examine the influence of narcissism on the CEO compensation level in high-technology firms. They find a positive relationship between a more narcissistic CEO with longer tenure with total direct compensation (salary, bonus, and stock options) and total shareholdings. In terms of social actions, Petrenko et al. (2016) and Al-Shammari et al. (2019) find a positive relationship between CEO narcissism and CSR activities. Interestingly, Al-Shammari et al. (2019) do not find any relationship between CEO narcissism and internally oriented CSR. This may indicate that narcist CEO uses CSR as a venue to get attention and build their self-image to the society.

Hogan and Kaiser (2005) and Olsen et al. (2014) mention that narcissism is related to several positive characters such as confidence, charisma, authority, and superiority. Those characters may be the reason why a narcist individual is frequently chosen as a leader. However, narcissism is also related to negative traits such as arrogance, self-importance, exhibitionism, entitlement, inability to learn from mistakes, and self-admiration (Emmons (1987); Hogan and Kaiser (2005); and Olsen et al. (2014)). Resick et al. (2009) argue that narcissism is related to a need for recognition and praise. Consequently, narcissism may result in reckless actions, especially those that are associated with an attempt to pursue goals or opportunities (Campbell et al. (2000) and Wallace and Baumeister (2002)).

Hambrick and Mason (1984) in their upper echelon theory, suggest managers' characteristics may influence the behavioural pattern of firms. They argue that individuals' way to select and process information is affected by their cognitive base and values. Hambrick (2007) argues that the personalities, experiences, and values of executives may affect their decision-making process. Therefore, how executives interpret situations and choose policies may also be affected by those characteristics. Kets de Vries and Miller (1985) argue that narcist executives concern about self-beneficial actions irrespective of the organization's interests. This characteristic may lead narcist CEOs to engage in self-favorable actions regardless of the impacts on others. Indeed, Duchon and Drake (2009), Amernic and Craig (2010) and Capalbo et al. (2018) find that in their attempt to achieve their goals, narcist individuals may engage in unethical behaviour. In a similar vein, Kontesa et al. (2021) find a positive relationship between CEO narcissism and earnings management. They suggest it is evidence of the attention and admiration seeking of narcist CEOs. Consequently, they choose actions that result in a higher personal reputation irrespective of the ethical perspective and the effect of those actions on their firm.

Lin et al. (2019) find a positive relationship between CEO narcissism and earnings management due to the pressure to meet earning threshold. They argue that it may result from narcist CEOs' attempts to get public attention and protect the social image. Moreover, Hales et al. (2012) find that a higher social image is an essential factor influencing why narcissism is related to the manipulation of public reports. Hence, there is a possibility that narcist CEO may manipulate public reports quantitively and qualitatively to achieve their personal goals. Therefore, the publicly available report, such as tax footnotes, can be a tool for narcist CEOs to achieve their personal gain. A narcist CEO may engage in actions irrespective of the ethical perspective, especially if those actions result in a better self-image. This may lead CEOs to manipulate the tax footnotes, thereby lowering the readability of the footnotes. However, there is also a possibility that narcissist CEO may write a smooth footnote to protect them from government scrutiny and also bad market assessments. In this case, CEO narcissism will lead to higher tax footnotes readability (more readable).

Based on the above premises, we propose the following hypothesis:

H0: there is no association of CEOs narcissism with tax footnotes readability in Indonesia. 


\section{METHODS}

\section{Sample and Research Design}

Section (1) Provides an explanation of our Tax footnote readability measure. We show our CEO Narcissism measure in Section (2). Section (3) Describes our sample selection. We explain our Research design process in Section (4).

\section{Tax Footnotes Readability}

We measure tax footnotes readability using the Fog Index. It is introduced by Robert Gunning in 1952 and has been used widely in the accounting literature. It captures the text complexity of the passage by calculating the number of words per sentence and the percentage of complex words. We measure the Fog Index as follows:

$$
\text { Fog }=(\text { words per sentence }+ \text { percentage of complex words }) * 0.4
$$

where complex words are multi-syllable words or words with three or more syllables (excluding proper nouns and compound words made from shorter words). We then follow Ajina et al. (2016) and Li (2008) 's classification: a text is unreadable if the Fog Index score is higher than eighteen, difficult if the index is between fourteen and eighteen, ideal readability if the index lies within twelve to fourteen, acceptable readability if the score is between ten and twelve, and childish if the index falls between eight and ten.

\section{CEO Narcissism}

Narcissists possess grandiose senses of self-importance, strong desires for recognition, and inflated selfconcepts, and they constantly seek opportunities for personal glory (Olsen and Stekelberg, 2016). We measure narcissism by following prior research by Olsen and Stekelberg (2016) by using the size and prominence of the CEO photograph, and rate each photograph on a scale from one to five as follows:

1. If annual report does not contain a photograph of the CEO.

2. If CEO was photographed with other executives.

3. If CEO was photographed alone and the photograph occupies less than half of a page.

4. If CEO was photographed alone and the photograph occupies at least half of a page, and the photograph shares the page with text.

5. If CEO was photographed alone and the photograph occupies the entire page.

\section{Sample Selection Process}

We initially collect all Indonesian-listed firms from the year 2015 - 2019. From 729 sample firms, we have excluded 369 firms with four excluded criteria. First, we excluded 107 firms operating in the financial services sector due to different operating and financial structures. Second, we exclude 108 firms with foreign reporting currencies to avoid currency translation errors due to different exchange rates in the year that could mislead our results. Third, we excluded 44 firms that have been delisted from BEI. Fourth, we excluded 150 firms with missing information. These Classification steps resulted in a final sample of 307 firms (799 firm-year observations)for our analysis. The sample selection procedures are shown in Table 1.

Table 1: Sample Selection Procedures

This table shows the sample selection procedures of our sample.

\begin{tabular}{lc}
\hline \multicolumn{1}{c}{ Criteria } & Firms \\
\hline Initial data set & 729 \\
Exclude: Financial services firms & 107 \\
Exclude: Firms with foreign reporting currencies & 108 \\
Exclude: Delisted firms & 44 \\
Exclude: Firms with missing information & 163 \\
\hline \multicolumn{2}{c}{ Total } \\
\hline
\end{tabular}

We presented our sample distribution in Table 2, where the annual distribution of our sample is presented in Panel A of Table 2, and the industry-wise distribution of our sample is presented in Panel B of Table 2. The Panel 
A of Table 2 shows that 31 per cent (263 firm-year observations) of our sample coming from the year 2019, while the year 2018 provides 23 per cent (201 firm-year observations).

Table 2: Sample Distribution

This table reports our sample characteristics. Reported percentages have been rounded.

\begin{tabular}{lcc}
\hline \multicolumn{3}{c}{ Panel A: Yearly Distribution } \\
\hline Year & Firm-Year & Percentage \\
\hline 2015 & 113 & $14 \%$ \\
\hline 2016 & 113 & $14 \%$ \\
\hline 2017 & 131 & $16 \%$ \\
\hline 2018 & 194 & $24 \%$ \\
\hline 2019 & 248 & $31 \%$ \\
\hline Total & 799 & $100 \%$ \\
\hline \multicolumn{1}{c}{ Industry } & Firm & Percentage \\
\hline & 91 & $11 \%$ \\
\hline Basic Materials & 131 & $16 \%$ \\
\hline Consumer Cyclicals & 178 & $22 \%$ \\
\hline Consumer non Cyclicals & 35 & $4 \%$ \\
\hline Energy & 35 & $4 \%$ \\
\hline Healthcare & 81 & $10 \%$ \\
\hline Industrials & 97 & $12 \%$ \\
\hline Infrastructures & 105 & $13 \%$ \\
\hline Properties and Real Estate & 12 & $2 \%$ \\
\hline Technology & 34 & $4 \%$ \\
\hline Transportation and Logistic & 799 & $100 \%$ \\
\hline Total & &
\end{tabular}

Panel B of Table 2 shows that the majority of our sample firms are in the service sector (infrastructures, properties and real estate, tranasportation and logistic) amounting to 30 per cent of the total sample data. In addition, firms from some sectors have a number that is not much different, that is the manufacturing sector (basic materials and industrials) amounting to 21 per cent of the total sample data, consumer non-cyclical sector amounting to 22 per cent, and consumer cyclical sector amounting to 17 per cent. Lastly, firms from energy sector amounting to 5 per cent, healthcare sector amounting to 4 per cent, and technology sector amounting to 2 per cent.

\section{Table 3: Correlation Matrix}

This table shows The Spearman correlation matrix for the sample of 799 firm-year observations for the period of 2015 2019.

\begin{tabular}{|c|c|c|c|c|c|c|c|c|c|c|c|c|}
\hline & 1 & 2 & 3 & 4 & 5 & 6 & 7 & 8 & 9 & 10 & 11 & 12 \\
\hline 1. GUNNINGFOG & 1.00 & & & & & & & & & & & \\
\hline 2.FLESCHKINCAID & 0.97 & 1.00 & & & & & & & & & & \\
\hline 3.SMOGINDEX & 0.97 & 0.95 & 1.00 & & & & & & & & & \\
\hline 4.AUTOMATEDREAD & 0.96 & 0.99 & 0.93 & 1.00 & & & & & & & & \\
\hline 5.CEOPHOTO & -0.06 & -0.02 & -0.06 & -0.04 & 1.00 & & & & & & & \\
\hline 6. AGE & 0.12 & 0.11 & 0.14 & 0.12 & -0.07 & 1.00 & & & & & & \\
\hline 7. SIZE & -0.08 & -0.07 & -0.10 & -0.06 & -0.35 & 0.14 & 1.00 & & & & & \\
\hline 8.MTB & 0.02 & 0.02 & 0.01 & 0.01 & 0.10 & -0.10 & 0.07 & 1.00 & & & & \\
\hline 9.ROA & 0.02 & -0.03 & 0.02 & 0.02 & 0.20 & 0.06 & 0.19 & 0.31 & 1.00 & & & \\
\hline 10. CTA & -0.02 & -0.01 & -0.02 & -0.01 & 0.10 & 0.08 & 0.06 & 0.19 & 0.41 & 1.00 & & \\
\hline 11. PTA & 0.09 & 0.08 & 0.12 & 0.09 & -0.01 & 0.10 & -0.05 & 0.04 & -0.06 & -0.25 & 1.00 & \\
\hline 12.ITA & -0.03 & -0.02 & -0.05 & -0.00 & 0.23 & 0.03 & 0.35 & 0.09 & 0.05 & 0.09 & 0.04 & 1.00 \\
\hline
\end{tabular}


Table 3 shows the correlation matrix of our sample. It shows that there is no indication of multicollinearity as a problem in estimating our baseline model.

\section{Baseline Model}

We run the following regression model to test the relationship between CEO narcissism and tax footnotes readability:

$$
\text { TFREAD }_{\mathrm{i}, \mathrm{t}}=\beta_{0}+\beta_{1} \text { NARCISTCEO }_{\mathrm{i}, \mathrm{t}}+\beta_{2} \text { CONTROLS }_{\mathrm{i}, \mathrm{t}}+\varepsilon .
$$

where, TFREAD is our tax footnotes readability measured by the Fog Index as in $\mathrm{Li}$ (2008); NARCISTCEO is the CEO narcissism measure in year $t$, and Controls is a vector of control variables in year $t$.

We include several control variables as in previous studies and variables that we believe will influence tax footnotes readability. Inger et al. (2018) argue that larger firms are more complex that may influence their tax compliance and tax planning, thereby affecting the readability of tax footnotes. We, therefore, include SIZE as measured by the natural logarithm of total assets. We include market-to-book $(M T B)$ as measured by the ratio of market capitalization to the difference between total assets and total liabilities to capture the market pressure on the readability of tax footnotes. Drake (2015) finds a relationship between the life cycle of a firm and booktax-difference. We then include firm age $(A G E)$ as our control variable. Inger et al. (2018) suggest that different performance levels may influence tax footnotes readability, we include return on assets $(R O A)$ to control firm profitability and performance. We include the ratio of property, plant, and equipment to the total assets (PPE) and intangible assets to the total assets (ITA) because the different treatment of those accounts on book and tax reporting may influence the readability of tax footnotes. We also include the ratio of cash to total assets $(C T A)$. To control the impact of firm specific and year effects on tax footnotes readability, we include the year and firm fixed effects. We winsorized all the continuous variables at the $1^{\text {st }}$ and $99^{\text {th }}$ percentiles to account for outliers. The Appendix provides detailed definitions of all the variables.

\section{RESULT AND DISCUSSION}

\section{Empirical Results}

This section shows the empirical results of the relationship between tax footnotes readability and CEO narcissism. Section 4.1 presents the statistical description of our sample. Section 4.2 shows the baseline regression results. And section 4.3 shows the additional analysis.

\section{Descriptive Statistics}

We present a summary of the statistics of our sample in table 3 . Table 3 shows that the mean of the tax footnotes readability (GUNNINGFOG) score of our sample is 20.32. Based on the standard interpretation of the index, the tax footnotes of Indonesian public companies are difficult to read and require college graduate-level comprehension. The mean (median) of CEOs photograph rating in the firms annual report is 3.756 (4.00) on a scale of one to five. For the control variables, the mean values of profitability $(R O A)$ and firm size (SIZE) are 3.8 per cent and 28.73, respectively. The average of market-to-book (MTB) and the cash to total assets (CTA) are 2.561 and 10.4 per cent, respectively. The mean (median) of the property, plant, and equipment to total assets (PTA) is 33.7 per cent (28.8 per cent). The mean of the intangible assets to total assets (ITA) is 2 per cent.

Table 4: Descriptive Statistics

This table reports the descriptive statistics for the sample of 799 firm-year observations for the period 2015-2019.

\begin{tabular}{lcccccccc}
\hline \multicolumn{1}{c}{ Variable } & N & Mean & SD & Min & P25 & Median & P75 & Max \\
\hline GUNNINGFOG & 799 & 20.32 & 1.976 & 15.20 & 19.10 & 20.40 & 21.50 & 25.30 \\
\hline FLESCHKINCAID & 799 & 16.72 & 1.786 & 12.00 & 15.60 & 16.80 & 17.80 & 21.70 \\
\hline SMOGINDEX & 799 & 14.65 & 1.184 & 11.50 & 13.90 & 14.70 & 15.40 & 17.80 \\
\hline AUTOMATEDREAD & 799 & 17.10 & 2.286 & 10.80 & 15.70 & 17.20 & 18.30 & 23.60 \\
\hline CEOPHOTO & 799 & 3.756 & 1.097 & 1.000 & 3.000 & 4.000 & 5.000 & 5.000 \\
\hline AGE & 799 & 34.74 & 18.91 & 3.000 & 22.00 & 34.00 & 44.00 & 100.0 \\
\hline SIZE & 799 & 28.73 & 1.630 & 25.15 & 27.47 & 28.70 & 29.99 & 32.35 \\
\hline MTB & 799 & 2.561 & 5.059 & -4.374 & 0.587 & 1.148 & 2.435 & 35.14 \\
\hline
\end{tabular}




\begin{tabular}{lllllllll}
\hline ROA & 799 & 0.038 & 0.090 & -0.249 & 0.001 & 0.031 & 0.071 & 0.424 \\
\hline CTA & 799 & 0.104 & 0.120 & 0.001 & 0.024 & 0.063 & 0.142 & 0.647 \\
\hline PTA & 799 & 0.337 & 0.245 & 0.002 & 0.143 & 0.288 & 0.493 & 0.918 \\
\hline ITA & 799 & 0.020 & 0.063 & 0.000 & 0.000 & 0.000 & 0.009 & 0.468 \\
\hline
\end{tabular}

\section{Baseline Results}

We began our analysis by regressing TFREAD with CEOPHOTO and reported the results in Table 5. We include our control variables, such as $A G E$, SIZE, MTB, ROA, CTA, PTA and ITA. We also exclude firm fixed effect and year fixed effect in our baseline regression model in estimating the relationship between CEO narcissism and tax footnotes readability.

Table 5: Tax Footnotes Readability and CEO Narcissism

This table shows linear regression results of the influence of CEO Narcisissm on the tax footnotes readability. We winsorize continuous variables at the 1 and 99 percent levels. We present the standard errors in parentheses. *, **, ***, indicate a statistical significancy level at the 10,5 and 1 percent levels respectively.

\begin{tabular}{lc}
\hline & TFREAD \\
\hline CEOPHOTO & $-0.206^{* *}$ \\
\hline AGE & $(0.092)$ \\
\hline & 0.005 \\
\hline SIZE & $(0.035)$ \\
\hline & -0.011 \\
\hline MTB & $(0.191)$ \\
\hline & -0.020 \\
\hline ROA & $(0.014)$ \\
\hline & 1.159 \\
\hline CTA & $(1.002)$ \\
\hline & 1.220 \\
\hline PTA & $(0.984)$ \\
\hline ITA & -0.027 \\
\hline & $(0.566)$ \\
\hline Constant & 2.901 \\
\hline Year Fixed Effect & $(3.074)$ \\
\hline Firm Fixed Effect & $20.50 * * *$ \\
\hline Adjusted R-Square & $(6.042)$ \\
\hline & YES \\
\hline & 0.769 \\
\hline & 799 \\
\hline & \\
\hline & \\
\hline
\end{tabular}

We find a negative (-0.206) relationship between TFREAD and CEOPHOTO and significant at 5 per cent level. It indicates that narcist CEOs tend to produce more readable tax footnotes. Therefore, this supports our argument that narcissist CEO may write a smooth footnote to protect them from government scrutiny and bad market assessments.

Related to our control variables,, we find that TFREAD is negatively related to MTB, SIZE and PTA and positively related to $A G E, R O A, C T A$, ITA. However, none of those relationships are significant at the confident level. 


\section{Additional Analysis}

In this section, we try to expand our analysis by examining the relationship between CEO narcissism and tax footnotes readability using alternative measures of tax footnotes readability. We present the result in Table 6. Specifically, Columns 1, 2, and 3 show the results of using the Flesch Kincaid, Smog Index, and Automated Readability Index as the specification to measure tax footnotes readability, respectively. Consistent with our baseline result, we find that CEOPHOTO is negatively (-0.183) related to TFREAD as measured using Flesch Kincaid methodology and statistically significant at 5 per cent level. Using Smog Index, we find a negative (-0.130) relationship between $\mathrm{CEO}$ narcissism and tax footnotes readability and significant at 5 per cent level. In Column 3, we find that CEOPHOTO is negatively (-0.264) related to TFREAD measured by Automated Readability Index specification and statistically significant at 5 per cent level.

Table 6 : Additional Analysis

This table shows linear regression results of the influence of CEO Narcisissm on the tax footnotes readability using alternative measure of tax footnotes readability. We use CEO photograph (CEOPHOTO) to measure CEO Narcisism. In column 1, we use Flesch Kincaid Index for our TFREAD. In Column 2, we use Smog Index for our TFREAD. In Column 3, we use Automated Readability Index. We winsorize our continuous variables at the 1 and 99 per cent levels. *, **, and ***, indicate a statistical significance at the 10,5 , and 1 per cent levels, respectively.

\begin{tabular}{|c|c|c|c|}
\hline & \multicolumn{3}{|c|}{ TFREAD } \\
\hline & (1) & (2) & (3) \\
\hline \multirow[t]{2}{*}{ СЕОРНОТО } & $-0.183^{* *}$ & $-0.130 * *$ & $-0.264 * *$ \\
\hline & $(0.083)$ & $(0.056)$ & $(0.106)$ \\
\hline \multirow[t]{2}{*}{ AGE } & 0.004 & 0.002 & 0.010 \\
\hline & $(0.032)$ & $(0.022)$ & $(0.041)$ \\
\hline \multirow[t]{2}{*}{ SIZE } & -0.001 & 0.017 & 0.055 \\
\hline & $(0.173)$ & $(0.117)$ & $(0.222)$ \\
\hline \multirow[t]{2}{*}{ MTB } & -0.009 & -0.007 & -0.017 \\
\hline & $(0.013)$ & $(0.009)$ & $(0.017)$ \\
\hline \multirow[t]{2}{*}{ ROA } & 1.151 & 0.730 & 1.528 \\
\hline & $(0.906)$ & $(0.614)$ & $(1.161)$ \\
\hline \multirow[t]{2}{*}{ CTA } & 0.651 & 0.772 & 0.814 \\
\hline & $(0.890)$ & $(0.603)$ & $(1.141)$ \\
\hline \multirow[t]{2}{*}{ PTA } & 0.193 & 0.059 & 0.285 \\
\hline & $(0.512)$ & $(0.347)$ & $(0.656)$ \\
\hline \multirow[t]{2}{*}{ ITA } & 2.525 & 1.896 & 3.120 \\
\hline & $(2.780)$ & $(1.885)$ & $(3.564)$ \\
\hline \multirow[t]{2}{*}{ Constant } & $16.25^{* *}$ & $13.85 * * *$ & $14.71 * *$ \\
\hline & $(5.787)$ & $(3.704)$ & $(7.005)$ \\
\hline Year Fixed effect & YES & YES & YES \\
\hline Firm Fixed Effect & YES & YES & YES \\
\hline R-Square & 0.769 & 0.759 & 0.768 \\
\hline Adjusted R-Square & 0.617 & 0.600 & 0,616 \\
\hline $\mathrm{N}$ & 799 & 799 & 799 \\
\hline
\end{tabular}




\section{CONCLUSION}

In this study, we investigate the relationship between tax footnotes readability and CEO Narcissism in Indonesia. With only a few prior studies undertaking research in the area of readability, we extended and contributed to the existing literature about tax footnotes readability and CEO narcissism, especially in Indonesia. We utilize CEO photograph to measure the narcissism of the CEO. Using 799 firm-year observations of 307 Indonesian listed firms listed in the Indonesian Stock Exchange during the 2015 - 2019 period. We find that CEO narcissism is related to a more readable tax footnotes. This result, therefore, support our argument that narcissist CEO may write a smooth footnote to protect them from government scrutiny and unfavourable market consequences. This result is validated by our additional examinations using alternative measures of tax footnotes readability. This study may shed light for further studies to examine other traits of CEO on the firm behaviour. Furthermore, it is interesting to see how executive traits interact with other factors, such as governance, in influencing firms' behaviour or performance.

\section{REFERENCE}

Adelberg, A. (1979). Narrative disclosures contained in financial reports: means of communication or manipulation?. Accounting and Business Research, 9, 179-189.

Ajina, A., Laouiti, M., \& Msolli, B. (2016). Guiding through the Fog: Does Annual Report Readability Reveal Earnings Management?. Research in International Business and Finance, 38, 509-516.

Aktas, N., De Bodt, E., Bollaert, H., \& and Roll, R. (2012). CEO Narcissism and the Takeover Process: From Private Initiation to Deal Completion, Available at SSRN: https://ssrn.com/abstract=1784322.

Ali, A., \& Zhang, W. (2015). CEO tenure and earnings management. Journal of Accounting and Economics, 59 (1), $60-79$.

Al-Shammari, M., Rasheed, A., \& Al-Shammari, H. A. (2019). CEO narcissism and corporate social responsibility: Does CEO narcissism affect CSR focus?. Journal of Business Research, 104, 106 - 117.

Amernic, J. H., \& Craig, R. J. (2010). Accounting as a Facilitator of Extreme Narcissism. Journal of Business Ethics, 96, 79 - 93.

Bloomfield, R.J. (2002). The 'Incomplete Revelation Hpothesis' and financial reporting. Accounting Horizons, $16,233-243$.

Bloomfield, R. J. (2008). Discussion of Annual report readability, current earnings, and earnings persistence. Journal of Accounting and Economics, 45, 248-252.

Botosan, C. (1997). Disclosure level and the cost of equity capital. The Accounting Review, 72, 323-349.

Campbell, W. K., Reeder, G. D., Sedikides, C., \& Elliot, A. J. (2000). Narcissism and comparative self-enhancement strategies. Journal of Research in Personality, 34 (3), 329-347.

Capalbo, F., Frino, A., Lim, M. Y., Mollica, V., \& Palumbo, R. (2018). The impact of CEO narcissism on earnings management. Abacus, 54 (2), 210 - 226.

Chatterjee, A., \& Hambrick, D. C. (2007). It's all about me: Narcissistic Chief Executive Officers and their effects on company strategy and performance. Administrative Science Quarterly, 52 (3), 351-386.

Courtis, J. K. (2004). Corporate report obfuscation: artefact or phenomenon?. British Accounting Review, 36 (3), 291-312.

Duchon, D., \& Drake, B. (2009). Organizational Narcissism and Virtuous Behavior. Journal of Business Ethics, $85,301-308$.

Drake, K. (2015). Does Firm Life Cycle Explain the Relation between Book-Tax Differences and Earnings Persistence? Working paper, The University of Arizona.

Emmons, R., A. (1987). Narcissism: Theory and measurement. Journal of Personality and Social Psychology, 52 
(1), $11-17$.

Ertugrul, M., Lei, J., Qiu, J., \& Wan, C. (2017). Annual report readability, tone ambiguity, and the cost of borrowing. Journal of Financial and Quantitative Analysis, 52(2), 811-836.

Foster, J. D., \& Campbell, W. K. (2007). Are there such things as "narcissists" in social psychology? A taxometric analysis of the Narcissistic Personality Inventory. Personality and Individual Differences, 43(6), 13211332.

Hales, J., Hobson, J. L., \& Resutek, R. J. (2012). The Dark Side of Socially Mediated Rewards: How Narcissism and Social Status Affect Managerial Reporting. Available at: http://papers.ssrn.com/sol3/papers.cfm?abstract_id $1 / 42021889$

Ham, C., Seybert, N., \& Wang, S. (2018). Narcissism is a bad sign: CEO signature size, investment, and performance. Review of Accounting Studies, 23(1), 234-264.

Hambrick, D. C. (2007). Upper echelons theory: An update. Academy of Management Review, 32 (2), 334-343.

Hambrick, D. C., \& Mason, P. A. (1984). Upper echelons: The organization as a reflection of its top managers. Academy of Management Review, 9 (2), 193 - 206.

Hirshleifer, D., Low, A., Teoh, S. (2012). Are Overconfident CEOs better Innovators? Journal of Finance, 67, $1457-1498$.

Hogan, R., \& Kaiser, R. (2005). What we know about leadership. Review of General Psychology, 9 (2), 169-180.

Huang, H. W., Rose-Green, E \& Lee, C. C. (2012). Age and Financial Reporting Quality. Accounting Horizons, 26 (4), 725-740.

Inger, K. K., Meckfessel, M. D., Zhou, M., \& Fan, W. (2018). An examination of the impact of tax avoidance on the readability of tax footnotes. The Journal of the American Taxation Association, 40(1), 1-29.

Kim, J. B., Wang, Z., \& Zhang, L. (2016). CEO Overconfidence and Stock Price Crash Risk. Contemporary Accounting Research, 33 (4), 1720-1749.

Kets de Vries, M. F., \& Miller, D. (1985). Narcissism and leadership: An object relations perspective. Human Relations, 38 (6), 583-601.

Kubick, T. R., \& Lockhart, G. B. (2017). Overconfidence, CEO Awards, and Corporate Tax Aggressiveness. Journal of Business Finance \& Accounting, 44 (5-6), 728-754.

Kontesa, M., Brahmana, R., \& Tong, A. H. H. (2021). Narcissistic CEOs and their earnings management. Journal of Management and Governance. 25, 223-249.

Lawrence, A. (2013). Individual investors and financial disclosure. Journal of Accounting and Economics, 56, $130-147$.

Lehavy, R., Li, F., \& Merkley, K. (2011). The effect of annual report readability on analyst following and the properties of their earnings forecasts. The Accounting Review, 86, 1087-1115.

Li, F. (2008). Annual report readability, current earnings , and persistence. Journal of Accounting and Economics, $45,221-247$.

Lim, E. K. Y., Chalmers, K., \& Hanlon, D. (2018). The influence of business strategy on annual report readability. Journal of Accounting and Public Policy, 37(1), 65-81.

Lin, F., Lin, S. W., \& Fang, W. C. (2019). How CEO narcissism affects earnings management Behaviors. North American Journal of Economics \& Finance, 51, 101080.

Lo, K., Ramos, F., \& Rogo, R. (2017). Earnings Management and Annual Report Readability. Journal of Accounting and Economics, 63, 1-25.

Maccoby, M. (2007). Narcissistic leaders: Who succeeds and who fails. Boston, MA: First Harvard Business School Press.

Malmendier, U., \& Tate, G. (2005). CEO overconfidence and corporate investment. Journal of Finance, 60(6), 2661-2700. 
Miller, B. P. (2010). The effects of reporting complexity on small and large investor trading. The Accounting Review, 85, 2107-2143.

Olsen, K. J., Dworkis, K. K., \& Young, S. M. (2014). CEO narcissism and accounting: A picture of profits. Journal of Management Accounting Research, 26 (2), 243-267.

Olsen, K. J., \& Stekelberg, J. (2016). CEO Narcissism and Corporate Tax Sheltering. The Journal of the American Taxation Association. 38 (1). 1 - 22.

O'Reilly, C. A., Doerr, B., Caldwell, D. F., \& Chatman, J. A. (2013). Narcissistic CEOs and executive compensation. The Leadership Quarterly, 25 (2). $218-231$.

Padilla, A., Hogan, R., \& Kaiser, R. B. (2007). The toxic triangle: Destructive leaders, susceptible followers, and conducive environments. The Leadership Quarterly, 18 (3), 176-194.

Petrenko, O. V., Aime, F., Ridge, J., \& Hill, A. (2016). Corporate Social Responsibility or CEO Narcissism? CSR Motivations and Organizational Performance. Strategic Management Journal, 37 (2), 262 - 279.

Raedy, J., Seidman, J. \& Shackelford, D. (2011). Is There Information Content in the Tax Footnote? Working paper, The University of North Carolina and University of Virginia.

Razak, L. A., Ramly, \& Badollahi, I. (2020). The Role of CEO Narcissism in Creating Firm Value (Study on BUMN Companies Listed on the Indonesia Stock Exchange 2015-2019). International Journal of Innovative Science and Research Technology, 5 (11), 221 - 225.

Resick, C. J., Whitman, D. S., Weingarden, S. M., \& Hiller, N. J. (2009). The bright-side and the dark-side of CEO personality: Examining core self-evaluations, narcissism, transformational leadership, and strategic influence. Journal of Applied Psychology, 94 (6), 1365-1381.

Rispantyo. (2019). Narsisme CEO dan Kualitas Laba. Research Fair Unisri, 3 (1), 347 - 351.

Rudman, L. A., Dohn, M. C., \& Fairchild, K. (2007). Implicit self-esteem compensation: Automatic threat defense. Journal of Personality and Social Psychology, 93(5), 798-813.

Rutherford, B. A. (2003). Obfuscation, textual complexity and the role of regulated narrative accounting disclosure in corporate governance. Journal of Management and Governance, 7, 187-210.

Sunder, J., Sunder, S. V., Zhang, J. (2017). Pilot CEOs and corporate innovation. Journal of Financial Economics, 123, 209-224.

Wallace, H. M., \& Baumeister, R. F. (2002). The performance of narcissists rises and falls with perceived opportunity for glory. Journal of Personality and Social Psychology, 82 (5), 819-834. 
Appendix: Variable Definitions

Variable

Definition

TFREAD Fog index is a readability test that aims to determine how easy a text to read based on reader's number of education to understand a particular text on the first reading.

CEOPHOTO A scale $1-5$ depends on the prominence of the CEO photograph in the annual report.

AGE

SIZE

The absolute value of firms age of firms $i$ in year $t$

MTB

The natural logarithms of firm $i$ total assets in year $t$

The result of multiplying the share price and the nu
difference between total assets and total liabilities.

ROA The ratio of net income to total assets.

CTA The ratio of cash divided to total assets.

PTA The ratio of property, plant and equipment to total assets.

ITA The ratio of total intangible assets to total assets. 